\title{
A Comparative Review of the Status of Domestic and Foreign Management Accounting Research in 2015-2017
}

\author{
Junzhuo Zhang \\ Department of Management, Jinan University, Guangzhou, China \\ Email: zjz502425@163.com
}

How to cite this paper: Zhang, J.Z. (2019) A Comparative Review of the Status of Domestic and Foreign Management Accounting Research in 2015-2017. Modern Economy, 10, 2355-2372.

https://doi.org/10.4236/me.2019.1012148

Received: November 11, 2019

Accepted: December 9, 2019

Published: December 12, 2019

Copyright $\odot 2019$ by author(s) and Scientific Research Publishing Inc. This work is licensed under the Creative Commons Attribution International License (CC BY 4.0).

http://creativecommons.org/licenses/by/4.0/

Open Access

\begin{abstract}
This paper summarizes and comments 68 papers published in five academic journals in management accounting from 2015 to 2017 and finds that the research topics and research methods are both diversified. Among them, there are more literatures on budget, salary and performance evaluation than other topics. Domestic research methods are mainly based on empirical research which are based on databases, and are relatively simple compared with the methods used by foreign research institutes, lacking a combination of multiple methods. Although domestic and foreign research basically has a relatively clear theoretical source, domestic research mostly cites existing foreign theories, lacks deep exploration of theory and forms China's own management accounting theory system. There are few sociological and psychological theories.
\end{abstract}

\section{Keywords}

Management Accounting, Comparative Review, Theory, Research Method

\section{Introduction}

Management accounting originated in Western countries, and was introduced from Western countries to China in the late 1970s and early 1980s. It has been developed for more than 40 years. With the steady development of China's economy since the reform and opening-up, the management level of domestic enterprises has gradually improved, and the importance of scientific management of enterprises has been increasingly valued by enterprises. As an emerging accounting branch, management accounting is gradually becoming well known and its application is also increasingly common and in-depth. Based on the un- 
derstanding of the importance of management accounting, the Royal Chartered Institute of Management Accountants and the American Institute of Certified Public Accountants jointly issued the Global Management Accounting Principles in 2014 to help organizations establish effective management accounting functions.

At the beginning of 2014, the Ministry of Finance issued the "Guiding Opinions of the Ministry of Finance on Promoting the Construction of the Management Accounting System (Draft for Comment)". This is the first time that China has officially proposed to comprehensively promote the construction of the management accounting system in China. The objectives, main tasks and measures of the system are described in detail. In 2016, the management accounting work was included in the "13th Five-Year Plan for Accounting Reform and Development". The Ministry of Finance officially issued the "Basic Guidelines for Management Accounting", which was implemented on June 22 of that year. It marks a new major breakthrough in the construction of China's management accounting system. This basic guideline serves as the guide for the application of the guidelines and sets out the principles and framework for the development of application guidelines. In October 2017, the Ministry of Finance issued the "Notice of the Ministry of Finance on Printing and Distributing 22 Management Accounting Application Guidelines" such as "Management Accounting Application Guide No. 100-Strategic Management" (hereinafter referred to as "Application Guidelines"), which summarizes and refines some of the mature management accounting tools that are currently widely used in enterprises. Application guidelines, as an important part of the management accounting guidance system, are the concrete reflection of the implementation of guidance and basic guidelines. It provides a reference on how to correctly and effectively choose and apply management accounting tools and methods.

In the basic theory of management accounting, Professor Yu Xuying and other scholars have been conducting comprehensive and in-depth exploration since the 1980s, and have made important contributions to the development of China's management accounting. In terms of applied research, domestic scholars and enterprises mostly draw on foreign excellent research results, combined with the unique situation of China, and achieved good research results.

At present, China's management accounting research has surpassed the constraints of the US management accounting framework, created its own advanced management accounting theory framework, and established a management accounting theory system with Chinese characteristics. However, if the international mainstream research standards are used as the benchmark, then the gap between the research or theory level of China's management accounting is still quite large. In a sense, China's management accounting theory is still behind practice. In some specific research fields and research objects, management accounting research has insufficient ability to lead the change of management practice frontier, and management accounting research itself is far from the ac- 
tivities and behaviors of its research objects. Management accountants in practice still play a lower-level role, that is, providers of information rather than management decision-makers, and thus there is a disconnection between theory and practice.

In view of this, in order to better understand the status of domestic and foreign management accounting research at home and abroad, this paper conducts a search and statistical analysis of the management accounting empirical literature of five top accounting academic journals in the past three years.

\section{Research Methods and Sample Selection}

At present, there are dozens of related journals in China's accounting field, because the core journals are more authoritative, and the types of articles published in theoretical journals and applied journals are different. Therefore, according to the research purpose, this paper selects papers published on Economic Research, Management World, Management Science from 2015 to 2017. Among the foreign journals, this paper selects two journal focuses on management accounting-Management Accounting Research and Accounting Organizations and Society as literature sources, which can basically reflect the frontier of management accounting research.

In order to ensure the scientific nature of the research, this paper considers the development and extension of management accounting, and supplements the research topics identified in the management accounting review research represented by Shields and Meng Yan, and finally takes the Operation Cost, Cost Driver, Target Cost, Quantitative Analysis, Cost Accounting, Cost Management, Management Control, Strategic Management, Value Chain Management, Operating Budget, Balanced Scorecard, Transfer Pricing, Accountability Accounting, Responsibility Reporting, Economic Value Added, Internal Reporting and Environmental Accounting as research topics and searched in the selected five journals, which were downloaded and saved as raw data. By reading the title, abstract and keywords of each article one by one, if the subject of the article can be classified into a research topic of management accounting in Table 1, then the article is included in the sample of this study, and then further read in details. After filter out irrelevant documents, 68 articles were obtained, wherein are 33 Chinese articles and 35 English articles, whose keywords are all management accounting related such as Cost Driver, Target Cost, Quantitative Analysis, Cost Accounting, Cost Management, Management Control, Strategic Management, Value Chain Management, Budget, Transfer Pricing, Accountability Accounting, Responsibility Reporting, Economic Value Added, Internal Reporting and Environmental Accounting.

\section{Management Accounting Research Review}

\subsection{Statistical Analysis of Research Topics}

In order to avoid the over-distribution of research topics, this paper refers to the 
Table 1. Annual distribution of research topics.

\begin{tabular}{|c|c|c|c|c|c|c|c|c|c|}
\hline & \multicolumn{4}{|c|}{ Domestic } & \multicolumn{4}{|c|}{ Foreign } & \multirow{2}{*}{ Total } \\
\hline & 2015 & 2016 & 2017 & Total & 2015 & 2016 & 2017 & Total & \\
\hline $\begin{array}{l}\text { Management } \\
\text { Control Systems }\end{array}$ & 7 & 7 & 2 & 16 & 6 & 8 & 2 & 16 & 32 \\
\hline $\begin{array}{l}\text { Cost Accounting } \\
\text { and Management }\end{array}$ & 0 & 0 & 0 & 0 & 1 & 0 & 0 & 1 & 1 \\
\hline $\begin{array}{l}\text { Decision-making } \\
\text { Methods }\end{array}$ & 0 & 1 & 0 & 1 & 0 & 0 & 0 & 0 & 1 \\
\hline $\begin{array}{c}\text { General Problems } \\
\text { of Management } \\
\text { Accounting }\end{array}$ & 1 & 2 & 2 & 5 & 1 & 2 & 3 & 6 & 11 \\
\hline $\begin{array}{l}\text { Externally oriented } \\
\text { Management } \\
\text { Accounting }\end{array}$ & 3 & 4 & 1 & 8 & 0 & 0 & 1 & 1 & 9 \\
\hline $\begin{array}{c}\text { Management } \\
\text { Accounting } \\
\text { Information } \\
\text { Systems }\end{array}$ & 0 & 0 & 0 & 0 & 0 & 1 & 0 & 1 & 1 \\
\hline Others & 1 & 2 & 0 & 3 & 3 & 6 & 1 & 10 & 13 \\
\hline Total & 12 & 16 & 5 & 33 & 11 & 17 & 7 & 35 & 68 \\
\hline
\end{tabular}

methods of Du Rongrui et al. [1] to distinguish the research topics of management accounting into Management Control Systems, Cost Accounting and Management, Decision-making Methods, General Problems of Management Accounting, and Externally oriented Management Accounting, Management Accounting Information Systems and other related issues.

It can be seen from Table 1 and Table 2 that the number of domestic management accounting articles in the past three years is 12,16 and 5 respectively, showing a trend of increasing first and then decreasing, which may be the reason for the small sample. Management Control Systems in all three years account for a large proportion (accounting for a total of $48.48 \%$ ), but the 2017 has a tendency to sag. The reason may be that Management Control Systems was a hot topic in the past years and there is no longer any space and necessity for further research since the AI and Cloud Computing are developing rigorously these days, which affect control systems a lot and related research needs an interdisciplinary perspective. A similar situation also exists in the externally oriented management accounting topic. In contrast, there is a lack of research on Cost Accounting and Management and Management Accounting Information Systems in China, the three domestic journals have not published relevant literature in the past three years.

The number of foreign literature of the past three years is 11 articles, 17 articles and 7 articles, but also the most in 2016. Similar to the status of domestic research, foreign articles on Management Control Systems also account for a 
Table 2. The proportion of research topics.

\begin{tabular}{|c|c|c|c|c|c|c|c|c|c|c|c|c|}
\hline & \multicolumn{4}{|c|}{ Domestic } & \multicolumn{6}{|c|}{ Foreign } & \multirow{2}{*}{ Total } & \multirow{2}{*}{ Proportion } \\
\hline & 2015 & 2016 & 2017 & Total & Proportion & 2015 & 2016 & 2017 & Total & Proportion & & \\
\hline $\begin{array}{l}\text { Management } \\
\text { Control Systems }\end{array}$ & 7 & 7 & 2 & 16 & $48.48 \%$ & 6 & 8 & 2 & 16 & $45.71 \%$ & 32 & $47.06 \%$ \\
\hline $\begin{array}{l}\text { Cost Accounting and } \\
\text { Management }\end{array}$ & 0 & 0 & 0 & 0 & $0.00 \%$ & 1 & 0 & 0 & 1 & $2.86 \%$ & 1 & $1.47 \%$ \\
\hline $\begin{array}{l}\text { Decision-making } \\
\text { Methods }\end{array}$ & 0 & 1 & 0 & 1 & $3.03 \%$ & 0 & 0 & 0 & 0 & $0.00 \%$ & 1 & $1.47 \%$ \\
\hline $\begin{array}{c}\text { General Problems of } \\
\text { Management Accounting }\end{array}$ & 1 & 2 & 2 & 5 & $15.15 \%$ & 1 & 2 & 3 & 6 & $17.14 \%$ & 11 & $16.18 \%$ \\
\hline $\begin{array}{c}\text { Externally oriented } \\
\text { Management Accounting }\end{array}$ & 3 & 4 & 1 & 8 & $24.24 \%$ & 0 & 0 & 1 & 1 & $2.86 \%$ & 9 & $13.24 \%$ \\
\hline $\begin{array}{l}\text { Management Accounting } \\
\text { Information Systems }\end{array}$ & 0 & 0 & 0 & 0 & $0.00 \%$ & 0 & 1 & 0 & 1 & $2.86 \%$ & 1 & $1.47 \%$ \\
\hline Others & 1 & 2 & 0 & 3 & $9.09 \%$ & 3 & 6 & 1 & 10 & $28.57 \%$ & 13 & $19.12 \%$ \\
\hline Total & 12 & 16 & 5 & 33 & $100.00 \%$ & 11 & 17 & 7 & 35 & $100.00 \%$ & 68 & $100.00 \%$ \\
\hline
\end{tabular}

large proportion (45.71\%), showing a trend of increasing first and then decreasing. In 2016, there were 8 articles, which were single-year single-topic peaks. However, slightly different from the domestic situation, there is a blank in the Decision-making Methods in foreign research, and there are many articles relating to General Problems of Management Accounting and other issues (17.14\% and $28.57 \%$ respectively), indicating the topics are more diverse and innovative in foreign research., such as articles based on psychology or human resource management theory, or articles using field research methods.

\subsection{Brief Description of Research Results}

\section{1) Management Control Systems}

Because the number of documents on Management Control Systems is the most, involving many research problems, in order to analyze the research more clearly, this paper has further classified under the first-level classification of Management Control Systems, and divided them into Budget Management, Performance Evaluation, Compensation System and Corporate Governance.

As can be seen from Table 3, the Journal of Management Science has not published relevant literature on Management Control Systems in the past three years. There are more literatures on Compensation System and Corporate Governance on the Journal of Management World and the Journal of Economic Research. The focus of the two foreign journals is Performance Evaluation. Next, this article will review the collated literature according to different topics.

a) Budget Management

As an important management and control activity of the company, budget management has two functions: incentives and planning. The incentive function 
Table 3. Annual distribution of research topic.

\begin{tabular}{|c|c|c|c|c|c|c|c|c|c|c|c|c|c|c|c|}
\hline & \multicolumn{3}{|c|}{$\begin{array}{c}\text { Journal of } \\
\text { Management World }\end{array}$} & \multicolumn{3}{|c|}{$\begin{array}{c}\text { Journal of } \\
\text { Economic Research }\end{array}$} & \multicolumn{3}{|c|}{$\begin{array}{c}\text { Journal of } \\
\text { Management Science }\end{array}$} & \multicolumn{3}{|c|}{$\begin{array}{c}\text { Journal of } \\
\text { Management } \\
\text { Accounting Research }\end{array}$} & \multicolumn{3}{|c|}{$\begin{array}{l}\text { Accounting } \\
\text { Organizations } \\
\text { and Society }\end{array}$} \\
\hline & 2015 & 2016 & 2017 & 2015 & 2016 & 2017 & 2015 & 2016 & 2017 & 2015 & 2016 & 2017 & 2015 & 2016 & 2017 \\
\hline Budget Management & 1 & & & & & & & & & 2 & 1 & & 1 & & \\
\hline Performance Evaluation & 2 & 1 & & & 1 & & & & & 2 & 3 & 1 & 1 & 2 & \\
\hline Compensation System & 1 & 2 & & & 1 & 1 & & & & & & 1 & & 2 & \\
\hline Corporate Governance & 3 & 2 & 1 & & & & & & & & & & & & \\
\hline
\end{tabular}

is expressed as the budget as the performance evaluation standard, and the budget completion is used as the main basis for calculating the compensation, and the execution efficiency and efficiency of the budget target in the enterprise are enhanced. This is mainly the budget execution process. The planning function is to set the resource allocation plan for future operation period before the enterprise to achieve the goal of achieving organizational goals and optimizing output efficiency.

Among the five selected journals, there have been five articles on budget management in the past three years, including one in the Journal of Management World, three in the Journal of Management Accounting Research, and one in Accounting, Organizations and Society.

Liu Hao et al. [2] used the income budget data disclosed by Chinese A-share listed companies to explore the relationship between internal control quality and budget execution results. The research results show that the enterprises with good internal control have better budget execution (small execution deviation and high compliance rate); however, enterprises with good internal control are more likely to have budget slack, and the more defined external business environment will weaken the above relationship between internal control and budget slack. Therefore, for budgetary activities, internal control may improve the efficiency of execution while making the management-level behavior tend to be conservative. In a broader sense, the benefits and costs brought about by internal control construction need to be considered comprehensively.

As an article on the study of budget slack, Jolien De Baerdemaeker et al. [3] studied the impact of participatory strategic planning on managers' budgetary slack. The author uses self-determination and organizational commitment theory to study the relationship between the degree of management layer involved in strategic planning and budget slack. These assumptions are empirically tested by survey data from 247 executives of the organizations in Western Europe. The results of the study show that increased participation in strategic planning can increase emotional organizational commitment, thereby creating lower budgetary redundancy. In addition, participatory budgeting reduces the generation of budget slack through the intermediary effect of autonomous budgetary motivation, indicating both two elements of organizational planning are 
related to the generation of budget slack.

b) Performance Evaluation

The research literature of four domestic performance evaluations is mainly aimed at the influence of the nature of an industry or a certain enterprise or the characteristics of senior executives on the performance of the enterprise, and proposes a corresponding performance evaluation framework or improves the original performance evaluation system, especially refined to the different nature based on the private or state-owned enterprise. These four articles are Private Enterprise Investor Background, Speculative Investment and Corporate Performance; An Empirical Study on the Change of State-owned Enterprise Executives; Managers' Military Experience, Financing Preferences and Business Performance; Can the Performance Appraisal System Promote the Innovation of Central Enterprises? However, the research in the field of nine foreign literatures is more focused on the impact of employee participation, individual performance, subjective evaluation on performance evaluation, as well as research on the performance of non-profit organizations; In terms of research methods, in addition to empirical research, there are also some foreign literatures that use laboratory research methods and research methods. It is worth noting that in the research of performance evaluation, most of the literature does not involve the theoretical basis, and only a small amount of literature applies relevant theories in research, such as the performance evaluation system based on stakeholder theory. For example, the papers named Fairness Perceptions of Annual Bonus Payments: The Effects of Subjective Performance Measures and the Achievement of Bonus Targets and Do the Incentive Effects of Relative Performance Measurement Vary With the Ex Ante Probability Of Promotion? Both are from The Journal of Management Accounting Research.

Liu Qingsong et al. [4] use data of A-share non-financial state-owned enterprise executives (general manager or chairman) between 2000 and 2012, with paired sample approach to study. The impact of the company's performance and the degree of social responsibility on executive change, the study found that executive change has a significant correlation with company performance. Specifically, the probability of executive demotion is negatively related to the company's performance. The probability of executive promotion is not related to the company's performance, but it is positively related to the social responsibility of the commitment. Further dividing the sample into the high-low performance of the industry based on the operating results, the two groups found that: when the performance is low, the executive change is significantly positively related to the performance, but not related to social responsibility; when the performance is high, the change is not related to performance, but is positively related to social responsibility.

Lai Li et al. [5] believed that the military experienced managers increased the company's debt and loan levels, increased the company's debt costs, lowered the level of cash holdings, and the company's operating performance was even 
worse. The impact of corporate finance and business performance is more pronounced in non-state-owned enterprises.

Jennifer Kunz [6] explored the relationship between autonomous motivation and performance evaluation system using experimental research methods. The author further divided the performance evaluation system into a system that only includes objective assessment and a system that combines subjective and objective factors. The results found that, because there are some subjective performance evaluation which is not accurate, and for lack of self-motivated people, objective and accurate assessment of the performance is better than contain inaccurate performance evaluation of subjective factors; For people of high self-motivation, the opposite is true.

Based on the theory of psychology and behavioral economics, Stephan Kramer et al. [7] conducted a laboratory experiment to study whether providing detailed relevant performance information (i.e. information about the specific performance level of peers) affects employee performance, and Whether a clear performance level ranking will affect an employee's response to relative performance information. The experimental results show that providing relative performance information will improve employee performance, but the relative performance data is similar in terms of whether they are presented in random order or in order of preference or suboptimal.

Bianca A C Groen et al. [8] considered appropriate and effective performance indicators to be an important means of translating organizational strategies into action. The authors examine whether managers believe that there are higher quality indicators for operational staff to participate in development and whether the use of these metrics is associated with higher employee performance. The paper surveyed 86 pairs of operational employees and their direct managers in various jobs and industries, and tested their hypotheses using equation models. The results of the study show that when employees participate in the development of performance indicators, managers believe that indicators are of higher quality and will use them more to evaluate and reward employees; when these indicators are used for evaluation purposes, employees will perform better. In short, the development of employee participation in performance indicators has a beneficial impact on the quality of indicators and the performance of future employees.

Jasmijn C. Bol [9] believes that companies can influence the manager's rating behavior by using the design of their control systems to influence the individual costs and benefits associated with the manager's rating decisions. The accuracy of the information that managers need to base their assessments and the transparency of performance assessments are two elements of control system design. The authors assume that improving the accuracy of information increases the extent to which managers distinguish between strong and vulnerable employees, but only when the results of the assessment are transparent. The experimental data obtained by the institute supports this hypothesis. 


\section{c) Compensation System}

The research on performance-oriented compensation system mainly discusses the issues related to the company's executive compensation. The research on executive compensation is mainly based on the prevailing salary control in China, and studies the key influencing factors of executive compensation (including equity structure, political factors, the nature of ownership, executive power, business risks), the gap between executive pay, executive pay affect business performance and salary disparities and other state-owned enterprises and private enterprises. After 2006, since the CSRC officially promulgated the Measures for the Administration of Equity Incentives for Listed Companies, a large number of researches on equity incentives began to appear. The research content also focused on the factors affecting the formulation of equity incentive plans and the impact of equity incentives on corporate performance. However, the above research on the compensation system adopts more research ideas and methods in the field of corporate finance, but the research topic belongs to the research category of management accounting. In the past three years, domestic research in this field has gradually expanded to the salary incentives of the manager and employee levels. Executives and employees are entrepreneurial value creators, all of which are important human resources to be motivated. Whether it is more effective in motivating executives or motivating employees, and the interaction between the two, the existing research has not given enough attention.

Chen Donghua et al. [10] used the listed companies in China as a sample to analyze the incentive effects and interactions of the two types of human resources. Specific consideration of the following three questions: 1) Whether the executives and staff salaries paid is sensitive to the performance or not? 2) What is the impact of the sensitivity of the two compensation performances on future performance? Is there a difference between the two? 3) What is the impact of executive compensation and employee compensation (measured by synchronization) on future performance? The study found that executives and employee compensation are sensitive to corporate performance, and executives' compensation performance sensitivity is significantly higher than that of employees, indicating that both types of incentives have a positive effect on future performance growth. In addition, a positive effect on the company's future performance weakens than executives; the stronger the executives and staff salaries paid change the synchronization, the more obvious positive effect on future performance. This paper introduced employee compensation research into the field of corporate governance research, and extended the principal-agent problem at the enterprise level to the staff level. By comparing the incentives of two types of human resources, it analyzed the role of two types of human resources in the process of enterprise performance creation and expanded the research in the incentives field.

Huang Jicheng et al. [11] took the A-share listed companies in China's Shanghai and Shenzhen stock markets from 2001 to 2012 as the research samples, and examined the impact of manager compensation incentives on the speed 
of capital structure adjustment, and explored its mechanism of action. The empirical test results showed that when the capital structure is lower than the target level, the higher the manager's salary, the faster the company adjusts the capital structure upwards. After considering other measures of the target capital structure, controlling the impact of corporate characteristics on the adjustment speed, and adopting the manager's salary change value, the above research conclusions remain unchanged. Further, when the effect of debt on the manager is stronger, the relationship between manager compensation and the speed of capital structure adjustment is more sensitive. This research confirmed the debt-constrained effect mechanism of the shareholder manager problem that affects the dynamic adjustment of capital structure proposed by the literature such as Morellec et al. (2012).

The income distribution effect of tax policy is the focus of attention in the academic and practical circles. Han Xiaomei et al. [12] took the 2008 salary offset tax reform as the background. Based on the company observations of the three years before and after the event, the double difference method was used to study the salary tax reduction brought by the salary tax reform impact. The study found that the salary and tax costs caused by the salary tax reform have been reduced, and the total salary of employees has been increased. The total salary increase is reflected in the increase in the average salary of employees, rather than the increase in the number of employees. The salary tax reform has mainly improved the average employees. The salary level, and reduce the salary gap between corporate executives and ordinary employees, and ultimately improve the company's total factor productivity. This effect is more pronounced in companies with lower wages, non-state-owned enterprises, and companies with lower dividend payout rates.

Although the income gap between corporate executives and ordinary employees has been widely concerned, how the internal income gap affects corporate innovation has not yet been discussed. In this context, Kong Dongmin et al. [13] used the data of Chinese listed companies to examine the impact of the pay gap between management and employees on corporate innovation. The study found that: First, the overall pay gap has a positive impact on innovation output. In order to control endogeneity, the article adjusts the construction tool variables based on the individual income tax rate and the minimum wage standard, and the conclusions are consistent. Second, in the case of low pay gaps, expanding the pay gap has significantly improved corporate innovation, indicating that tournament theory dominates innovation activities; but in the case of higher pay gaps, expanding the pay gap has a bearing on corporate innovation. The negative effect indicates that the comparative theory begins to play a role. Third, the positive incentive effect of the pay gap on innovation is mainly driven by the management pay premium, and the employee compensation premium reduces the innovation output to some extent.

Gao et al. found that executives' "job-hopping" behavior has a significant im- 
pact on corporate compensation contracts. When executives are more liquid in the labor market, companies usually increase salary incentives of their current executives. In addition, Rhodes empirically found that in addition to the CEO's own contract with the company's compensation contract, the company's debt contract also has an impact on the CEO's incentive effect, and the sensitivity of CEO compensation to corporate performance is determined by the debt terms. The degree of relaxation is different. Regarding the performance evaluation of general employees, Bol et al. found through experimental research that the two control system designs will affect the private costs and benefits generated by the managers to evaluate the subordinates, thus affecting the evaluation of employee performance evaluation: one is management The evaluation of the accuracy of the information on which it is based, and the transparency of the results of its performance evaluation [9].

d) Corporate Governance

Most domestic research on corporate governance focuses on the role of non-executive directors and the relationship between shareholders and managers. Huang Haijie et al. [14] used the private listed companies in China from 2007 to 2012 as a sample to study the impact of the reputation of non-executive directors on the quality of earnings from the perspective of independent accounting professionals. The study found that the reputation of the independent director of accounting has a significant positive impact on the quality of corporate earnings, and this influence is highly valued in accounting professionals who are employed by large shareholders in short-selling, low-marketing countries and as chairman of the audit committee. Chen Donghua et al. [15] used the sample of A-share listed companies in China from 2003 to 2013 as a sample to study the rationality of the term of independent directors. Through empirical research, it found that the effectiveness of independent directors increased continuously with the marginal decline in the extension of the term. Influenced by the financial background of the independent directors and the reputation cost, the empirical evidence of the article supported the appropriate extension of the term of the independent directors to alleviate the structural difficulties of the independent directors due to the Changing Difficulties and the Resignation Tide faced by listed companies.

In addition, Lu Zhengfei et al. [16] believe that non-executive directors directly elected by major shareholders and other significant influence shareholders may be more independent of management. Therefore, non-executive directors may have more control effect on management than independent directors. The study found that non-executive directors have a significant inhibitory effect on the smoothing of earnings by management. When the equity balance is high, the non-executive directors have more obvious inhibition on earnings smoothing. Compared with the state-owned background, the non-executive directors in the non-state-owned background have more obvious inhibitory effects on earnings smoothing. 
Shao Shuai et al. [17], through an empirical analysis of A-share private listed companies from 2004 to 2012, found that natural person directly holding companies have higher accounting performance (ROA and ROE) and market performance (Tobin's Q) than pyramid-structure companies. It also confirms the three ways in which direct shareholding enhances corporate value by improving corporate governance, that is, the lower the probability of actual controller change in the direct shareholding company is, the more willing the actual controller to operate for a long time. This paper found a mechanism to reduce agency costs from the perspective of equity arrangement and gave a path to improve corporate governance structure.

\section{2) Cost Accounting and Management}

Since Anderson, Banker and Janakiraman discovered the phenomenon of Cost Stickiness, many scholars both domestic and overseas began to explore related issues. George Venieris et al. investigated how the company's perception of intangible economic sacrifices affects the volatility of sales and management (SG\&A) expenses [18]. The author believes that in the case of declining sales, companies with more intangible assets use more unused resources than those with less intangible assets. This is because more intangible investments increase the level of adjustment costs and drive managers to expect more optimistic expectations that future sales growth will absorb slack in unused resources.

\section{3) Decision-Making Method}

When summarizing the irrational characteristics of decision makers, Chen Shihua [19] examined the anchoring effect in M\&A premium decision. Based on the sample of M\&A events of China's A-share listed companies from 2004 to 2011, the research results show that although the M\&A premium decision is dominated by rational factors, there is also a certain degree of anchoring effect.

\section{4) General Issues of Management Accounting}

The literature on this topic includes five articles in China and five articles in foreign countries. How to improve corporate performance is a hot topic in management accounting research, and it is general, so it falls under such topics. Zhang Xiangjian et al. [20] studied the relationship between executives' elite governance model and corporate performance. The article argued that CEO's control can improve corporate performance by improving resource allocation and innovation capabilities. There is an inverted U-type between CEO social association and corporate performance. Relationships are attributed to the combined effect of performance improvement effects and performance impairment effects caused by social associations. Hao Yang et al. [21] examined the impact of state-owned and private equity shareholders on company performance and its mechanism of action. He believed that the "mixed-owner" equity structure improved company performance, but equity diversification among state-owned capital was not positive for company performance. The impact of private equity participation has increased the sensitivity of state-owned enterprise management's compensation and turnover to performance. State-owned shares have 
reduced the tax burden and financing constraints of private enterprises, and the lower the marketization, the more positive the impact of heterogeneous shareholder participation on performance. From the perspective of self-protection of institutional investors, Zhang Dixin et al. [22] reveals the micro-mechanism of institutional investors' influence on the performance of their holding companies by constructing a game model of internal and institutional investors. Institutional investors have significantly improved the performance of their holding companies, but the improvement in the latter stage has been significantly weakened, the fund helps to improve the performance of its holding companies, while other institutional investors lack this improvement.

Luft et al. [23] reviewed a series of experimental studies on the impact of survey management control systems on competition and cooperation between employees, and analyzed the role of management control systems in social comparison, competition incentives, support cooperation in the organization and the role of teamwork and reciprocity in the process. Clara Xiaoling Chena et al. [24] used abstract experiments to test how the interaction between classification predictions and performance-based incentives affects the accuracy and optimism of predictions. They found that classification predictions lead to the absence of performance-based incentives, improve the accuracy of predictions and predict the increase in optimism.

\section{5) Externally oriented Management Accounting}

The literature on this topic in this sample is mostly concentrated in China, and most of them focus on the relationship between strategy and firm performance. Wang Kemin et al. [25] studied the relationship between industrial policy, government support and corporate investment efficiency. The article argues that in order to promote regional economic development, local governments prefer to provide financial support for local companies based on national industrial policies. However, between government and companies, information asymmetry may reduce resource allocation efficiency, trigger excessive investment, and harmly affect the effect of the implementation of the industry policy.

Wang Wei et al. [26] examined the impact of four types of control rights changes on company performance in the case of listed companies with the ultimate controller change in A-shares from 2003 to 2011. They believed that the change in the nature of property rights played a role in the transfer of control rights. The positive role, the research results show that: state-owned transfers to private and private transfer to the state-owned can both significantly improve the company's performance, while the state-owned and private transfer to the private sector not significantly improve the company's performance. Wu Yuhui et al. [27] studied the impact and impact mechanism of venture capital intervention on long-term and short-term business performance. The research results showed that venture capital intervention only brings financial support to enterprises and improves their short-term business performance, but It does not bring more value-added services to sustainable growth. 


\section{6) Management Accounting Information System}

The main research of management accounting information system is to manage the usefulness of accounting information. There is only one paper in this research field in the sample, which is the article published by Thomas in Accounting, Organizations and Society. The authors examine whether providing feedback on short-term management accounting information system adjustments will trigger more subsequent adjustments, and the results of the experiment found that it depends on whether the feedback information sets the organization's members to a long-term high standard goal.

\section{7) Other Issues}

In addition to the above topics, some of the cross-cutting and research review literatures are included in this category. For example, Xu Liping et al. [28] studied 13 listed companies with executive marriages as of the end of 2014, and in-depth study showed the impact of executive marriage on corporate governance, stock price performance and company performance. Corporate performance has a profound impact. After the divorce of executives, the company's profitability declines, stock valuations decline, stock volatility intensifies, capital expenditures decrease, and debt levels decrease. Based on the regional cultural background and social identity theory represented by dialects, Dai Yiyi et al. [29] analyzed the influence mechanism of the dialect consistency of the chairman and general manager on the interaction between the two parties. It was found that the consistency in dialect of the chairman and general manager can significantly reduce agency costs. The narrower the use of a dialect, the more significant the effect.

\section{Summary}

In summary, the research topics of management accounting literature domestic and overseas are quite extensive, and the application of research methods also presents a diversified situation. Similar to the research results of Meng Yan et al. [30], the research on executive compensation and equity incentives in China is mainly based on the salary control in China. The research on salary incentives and performance evaluation still maintains a considerable proportion. The related research on cost accounting \& management and activity cost method is also significantly reduced; it focuses more on cost stickiness. In addition, there are quite a lot of discussions on the theoretical framework of the nature and role of management accounting, indicating that scholars are paying more and more attention to management accounting theory research.

In the past three years, there has not been a lot of literature on the general problems of the Management Control System itself, but more about the research of its sub-categories. At the same time, there are few studies on the overall integrity of the Management Accounting Information System in China. The usefulness of accounting information is relevant; there are many related researches on externally oriented management accounting and strategic management ac- 
counting. There are still some differences in research methods at home and abroad. Most of the literatures in domestic research adopt database-based empirical research methods, while foreign research methods are more diversified.

At the same time, although this article does not separately report the theoretical basis of the literature, it is not difficult to see in the reading process that there are some theoretical foundations involved in management accounting research, and various theoretical applications are diverse, specifically covering the Principal-agent theory, asymmetric information theory, contract theory, social comparison theory, cognitive theory, championship theory, fair theory, incentive theory, prospect theory, etc. The principal frequency of the principal-agent theory framework is the highest. However, compared with foreign countries, domestic management accounting research adopts empirical research methods based on empirical data. Many of the literatures only describe the concept and application of existing foreign theories, and the theoretical height is still lacking. The management accounting theory system under the special system still has a long way to go. In addition, the theoretical basis of domestic research is mainly based on the theory of economics. The related theories of sociology and psychology are relatively few, which may lead to limited understanding of the subject of research.

\section{Main Contribution}

China's management accounting research is still based on economic theory. Compared with foreign countries, there are few management accounting studies in applied sociology and psychology. The theoretical perspective of the new institutional economics (transactional economics) is difficult to analyze the process of management accounting changes. Although the domestic research on management accounting reform has discussed the management accounting changes of Chinese enterprises, it does not address the path of change and mode and build up a sound theoretical framework with obstacles encountered in the transformation. The motivation of this paper is to summarize the trend of management accounting research and inspire a new direction of future management accounting reform based on the different perspectives of sociology and psychology. This paper provides some reference value to the research field on how to successfully introduce advanced management and control systems and improve management accounting levels.

\section{Insufficient Research and Future Prospects}

This paper attempts to sort and classify the management accounting literature in the past three years according to the research topic, but there are some limitations. First of all, the selected literature is selected by the author of this paper, the sample selection is anti-randomness, and the representativeness of the sample may be affected to some extent. Therefore, this paper does not take the method of Meng Yan et al. (2014) to test the statistical significant difference between the 
data and the results of other similar studies. Secondly, management accounting itself has a cross relationship with many disciplines from the beginning of its development, such as traditional financial accounting, corporate finance, finance, behavioral science, etc. in view of my limited understanding of the essence and connotation of management accounting, this paper may not be accurate and detailed in the classification of management accounting research topics. In addition, this paper only selects five representative journals at home and abroad for retrieval and screening, which may lead to a small number of studies observed under some topic classifications, so the trend analysis of research status is not so accurate.

According to the simple collation and comparison of domestic and foreign management accounting documents in recent three years, and the above comments, the future management accounting research in China can be improved from several aspects. Firstly, rooted in the practice of Chinese enterprises, gradually broaden the scope of research topics, explore the special problems presented in the Chinese context, and at the same time, conduct in-depth exploration and exploration of the existing theory, find the connection point that is consistent with Chinese practice, and on this basis refine and sublimate the unique theoretical framework system of management accounting in China, so as to better guide the practice. Second, pay attention to the matching of research methods, research theories and research topics, and further use a variety of research methods in an innovative way, integrate the theoretical basis of various fields to explain the phenomenon, and view the problem in a more diversified perspective, so as to draw a more comprehensive and novel conclusion.

\section{Conflicts of Interest}

The author declares no conflicts of interest regarding the publication of this paper.

\section{References}

[1] Du, R.R., Xiao, Z.Z. and Zhou, Q.W. (2009) Review of China's Management Accounting Research. The Journal of Accounting Research, No. 9, 72-80+97.

[2] Liu, H., Xu, N. and Shi, S.H. (2015) Internal Control "Double-Edged Sword" Effect-Studies on the Budget and Budget Execution Relaxation. The Journal of Management World, No. 12, 130-145.

[3] De Baerdemaeker, J. and Bruggeman, W. (2015) The Impact of Participation in Strategic Planning on Managers ' Creation of Budgetary Slack: The Mediating Role of Autonomous Motivation and Affective Organisational Commitment. The Journal of Management Accounting Research, 29, 1-12. https://doi.org/10.1016/j.mar.2015.06.002

[4] Liu, Q.S. and Xiao, X. (2015) Failure Performance, Success Performance? Empirical Research on the Change of State-Owned Enterprise Executives. The Journal of Management World, No. 3, 151-163.

[5] Lai, L., Gong, Y.L. and Ma, Y.Q. (2016) Managers' Military Experience, Financing Preferences and Business Performance. The Journal of Management World, No. 8, 
126-136.

[6] Kunz, J. (2015) Objectivity and Subjectivity in Performance Evaluation and Autonomous Motivation: An Exploratory Study. The Journal of Management Accounting Research, 27, 27-46. https://doi.org/10.1016/j.mar.2015.01.003

[7] Kramera, S., Maasb, V.S. and Van Rinsuma, M. (2016) Relative Performance Information, Rank Ordering and Employee Performance: A Research Note. The Journal of Management Accounting Research, 33, 16-24. https://doi.org/10.1016/j.mar.2016.03.004

[8] Groen, B.A.C., Wouters, M.J.F. and Wilderom, C.P.M. (2017) Employee Participation, Performance Metrics, and Job Performance: A Survey Study Based on Self-Determination Theory. The Journal of Management Accounting Research, 36, 51-66. https://doi.org/10.1016/j.mar.2016.10.001

[9] Bol, J.C., Kramer, S. and Maas, V.S. (2016) How Control System Design Affects Performance Evaluation Compression: The Role of Information Accuracy and Outcome Transparency. Accounting, Organizations and Society, 51, 64-73. https://doi.org/10.1016/j.aos.2016.01.001

[10] Chen, D.H., Fan, Y. and Shen, Y.J. (2015) Executives and Employees: Comparison and Interaction of Incentive Effectiveness. The Journal of Management World, No. $5,160-171$.

[11] Huang, J.C., Yan, Z., Zhu, B. and Zheng, Z.G. (2016) Managerial Compensation Incentives and Dynamic Adjustment of Capital Structure. The Journal of Management World, No. 11, 156-171.

[12] Han, X.M., Gong, Q.H. and Wu, L.S. (2016) Salary Tax Credit and Corporate Salary Arrangement. The Journal of Economic Research, No. 10, 140-154.

[13] Kong, D.M., Xu, Y.L. and Kong, G.W. (2017) Internal Salary Gap and Innovation in Enterprises. The Journal of Economic Research, No. 10, 144-157.

[14] Huang, h.J., Lv, C.J. and Ding, H. (2016) Independent Directors Reputation and Earnings Quality-Accounting Professional Independent Director's Perspective. The Journal of Management World, No. 3, 128-143+188.

[15] Chen, D.H. (2017) Independent Director Can Be Renewed Only 6 Years It Is Reasonable? China Based a Empirical Study of the Listed Companies. The Journal of Management World, No. 5, 144-157.

[16] Lu, Z.F., Hu, Y. (2015) Shareholder-Manager Agency Conflict and the Role of Non-Executive Directors of Governance: From China a Evidence-Share Market. The Journal of Management World, No. 1, 129-138.

[17] Shao, S. and Lu, C.J. (2015) Can the Actual Controller Directly Hold Shares to Increase the Company's Value? Evidence from Chinese Private Listed Companies. The Journal of Management World, No. 5, 134-146+188.

[18] Venieris, G., Naoum, V.C. and Vlismas, O. (2015) Organisation Capital and Sticky Behaviour of Selling, General and Administrative Expenses. The Journal of Management Accounting Research, 26, 54-82. https://doi.org/10.1016/j.mar.2014.10.003

[19] Chen, S.H. and Li, W.A. (2016) Research on Anchoring Effect in M \& A Premium Decision. The Journal of Economic Research, No. 6, 114-127.

[20] Zhang, X.J., Xu, J. and Xu, L.B. (2015) Can the Executive Elite Governance Model Improve Corporate Performance? Research on the Adjustment Effect Based on Social Connection Relationship. The Journal of Economic Research, No. 3, 100-114.

[21] Hao, Y. and Gong, S. (2017) State-Owned, Private Equity and Mixed Company Performance Improvement. The Journal of Economic Research, No. 3, 122-135. 
[22] Zhang, D.X. and Li, Z.H. (2017) Research on The Influence of Institutional Investors on The Performance of Their Shareholding Companies-Based on The Perspective of Institutional Investors' Self-Protection. The Journal of Management Sciences, No. 5, 82-101.

[23] Luft, J. (2016) Cooperation and Competition among Employees: Experimental Evidence on The Role of Management Control Systems. Management Accounting Research, 31, 75-85. https://doi.org/10.1016/j.mar.2016.02.006

[24] Chen, C.X., Rennekamp, K.M. and Zhou, F.H. (2015) The Effects of Forecast Type and Performance-Based Incentives on The Quality of Management Forecasts. Accounting, Organizations and Society, 46, 8-18. https://doi.org/10.1016/j.aos.2015.03.002

[25] Wang, K.M., Liu, J. and Li, X.X. (2017) Research on Industrial Policy, Government Support and Corporate Investment Efficiency. The Journal of Management World, No. 3, 113-124+145+188.

[26] Wang, W. and Hu, J. (2016) Transfer of Control Rights, Nature of Property Rights and Corporate Performance. The Journal of Economic Research, No. 4, 146-160.

[27] Wu, Y.H., Feng, W.C. and Wu, S. (2016) Venture Capital Intervention Will Improve Business Performance It? Evidence Based on China's Gem Listed Companies. The Journal of Management Sciences, No. 7, 85-101.

[28] Xu, L.P., Lai, D.D. and Xin, Y. (2015) Unbearable Weight: Research on the Economic Consequences of Corporate Executive Marriage. The Journal of Management World, No. 5, 117-133+159.

[29] Dai, Y.Y., Xiao, J.L. and Pan, Y. (2016) “Accent” Could Reduce the Company's Agency Costs? Research Perspective Based on the Dialect. The Journal of Economic Research, No. 12, 147-160+186.

[30] Meng, Y., Sun, J., Lu, W. and Liu, J.Y. (2014) Review and Prospect of China's Management Accounting Research. The Journal of Accounting Research, No. 9, 3-12+96. 